Marian J. Ptak

Uniwersytet Wrocławski e-mail: avis@prawo.uni.wroc.pl

telefon: +48713752761

DOI: $10.15290 /$ mhi.2015.14.02.13

\title{
Suplement do chronologii zgromadzeń stanowych Księstwa Głogowskiego (1257-1786)
}

\begin{abstract}
SUMMARY
Supplement to the Chronology of the Estate's Assemblies of the Duchy of Głogów (1257-1786)

The text is a supplement to the chronological presentation of the Estate's Assemblies of the Duchy of Głogów, prepared in 1991 by the author in his monographic book on this topic. One can prove that the first traces of the Assembly, composed from the chivalry, can be found in the middle of the 13th century. The well developed system of the estate's assemblies in the Duchy of Głogów was liquidated after the annexion of Silesia by Prussia in 1742. The king of Prussia decided to retain only one of its elements, the so called Weichbildtag, composed of circles (Kreis) of noblemen with only limited competences. The lack of archive documents from this period results in the supplement providing only one reference to Weichbildtag in Głogów in 1786.
\end{abstract}

Key words: Silesia, Duchy of Głogów, estates, estate’s assemblies

Słowa kluczowe: Śląsk, Księstwo Głogowskie, stany, zgromadzenia stanowe

Przed ponad dwudziestu laty ukazała się moja rozprawa habilitacyjna poświęcona aktywności politycznej stanów Księstwa Głogowskiego, jednego z największych i najważniejszych księstw śląskich, w którym władzę książęcą sprawowali nie tylko Piastowie, ale również Luksemburgowie, Jagiellonowie i Habsburgowie, a więc przedstawiciele czołowych dynastii panujących w ówczesnej Europie ${ }^{1}$. Zdumiewająca okazała się w związku z tym trwałość znacze-

1 M. Ptak, Zgromadzenia i urzędy stanowe księstwa głogowskiego od początku XIV w. do 1742 r., Acta Universitatis Wratislaviensis nr 1344, Prawo CCX, Wrocław 1991. Jej recenzentem został, znany mi z publikacji o sejmikach ziemskich Rzeczypospolitej, ale wówczas nie osobiście, prof. dr hab. Adam Lityński. Recenzja była dla mnie bardzo pochlebna, co zachowam zawsze we wdzięcznej pamięci. 
nia stanów oraz różnorodnych form ich partycypowania w życiu politycznym tego księstwa aż do połowy XVIII stulecia. Materiały źródłowe, na których przyszło się oprzeć, okazały się skrajnie zdekompletowane i rozproszone, co narzuciło uciążliwą i czasochłonną metodę przeglądania publikacji o różnym charakterze oraz archiwaliów pochodzących z wielu archiwów, zespołów i jednostek archiwalnych, często o tytułach niemających bezpośredniego związku $\mathrm{z}$ prowadzonymi badaniami. Uzyskane $\mathrm{w}$ ten sposób wiadomości, dotyczące najważniejszej formy ich aktywności czyli zgromadzeń stanowych, zostały zebrane $\mathrm{w}$ chronologicznym wykazie uwzględniającym różne ich rodzaje. $\mathrm{W}$ trakcie dalszych badań nad ustrojem i prawem Księstwa Głogowskiego oraz innych terytoriów Śląska okazało się, że da się go wzbogacić o kolejne wzmianki źródłowe. Zamieszczam je poniżej w porządku chronologicznym, ale w szerszych ramach czasowych i bez podziału na rodzaje zgromadzeń. Wątpliwości dotyczące daty rocznej, miesięcznej i miejsca odbycia zgromadzenia zaznaczam pytajnikiem (?).

$1257(?)$

- 1 IX, (?) zjazd rycerstwa głogowskiego. Dokument biskupa wrocławskiego Tomasza stwierdzający przekazanie klasztorowi z Nowogrodu Bobrzańskiego dziesięciny z Jabłonowa coram domino duce Conrado et suis militibus omnibus ${ }^{2}$.

1294

- Przed i po 6 V, Głogów (?), sejmik Księstwa Głogowskiego. Dokument Henryka V wrocławskiego z 6 V 1294 r. potwierdzający przekazanie Henrykowi I głogowskiemu terytoriów w trybie polubownym mit gutem villen nach unser getruwer rate, zawierający poręczenie dwóch grup rycerzy Henryka V (10 i 50 osób) $)^{3}$.

\section{6}

- 15 VIII, in castro Glogovie, sejmik Księstwa Głogowskiego. Dokument Henryka I głogowskiego poświadczający zamianę rycerzowi Gebhardowi połowę Prusic i dwóch wsi za zamek, miasto i dystrykt żmigrodzki commutato consilio maturo nobilium terre nostre et sapientum ${ }^{4}$.

2 Codex Diplomaticus Silesiae (dalej: CDS), t. IV, s. 295; Neues Archiv für die Geschichte Schlesiens und der Lausitz, t. II, wyd. J.G. Worbs, s. 161; CDS, t. VII, cz. 2, Breslau 1875, Regesten zur schlesischen Geschichte (RS), nr 981.

3 Lehns- und Besitzurkunden Schlesiens und seiner einzelnen Fürstenthümer im Mittelalter, wyd. C. Grünhagen, H. Markgraf, cz. II, Leipzig 1883 (dalej: GM II), s. 3-8.

4 Urkundensammlung zur Geschichte des Fürstentums Oels bis zum Aussterben der Piastischen Herzogslinie (dalej: UO), wyd. W. Haeusler, Breslau 1883, nr 105. 


\section{7}

- 3 II, Głogów, sejmik Księstwa Głogowskiego. Henryk I głogowski in presentia nostra nostrorumque nobilium terre, qui ad hoc vocati et rogati fuerunt potwierdził prawa żony dziedzica Prusic ${ }^{5}$.

\section{8}

- 2 VII, Oleśnica, sejmik Księstwa Głogowskiego. Henryk I głogowski maturo nostrorum fidelium consilio zwolnił majątek rycerza od wszystkich służebności i nadał mu uprawnienia sądownicze ${ }^{6}$.

\section{2}

- 29 II, Głogów, sejmik Księstwa Głogowskiego. Dokument podziału Księstwa Głogowskiego i części Wielkopolski (Poznań, Gniezno, Kalisz), wystawiony przez książąt głogowskich (Henryk II, Jan, Przemko, Konrad, Bolko) $\mathrm{z}$ bezpośrednim udziałem przedstawicieli rycerstwa ${ }^{7}$.

\section{$1315(?)$}

- (?) Rejestr podatkowy dystryktu głogowskiego i polkowickiego ${ }^{8}$.

\section{6}

- 29 VII, Głogów, sejmik Księstwa Głogowskiego. Rewers tej samej daty Henryka żagańskiego dla Głogowa, zawierający potwierdzenie dotychczasowych praw miasta, wydany mit bedachtim mute und mit gutin willin und mit unsir getruen manne rate 9 . Dokument wystawiony przez konsulów i gminę Głogowa stwierdzający złożenie hołdu (verum homagium) Henrykowi żagańskiemu i Janowi ścinawskiemu ${ }^{10}$.

\section{9}

- Przed 9 V, Głogów (?), sejmik Księstwa Głogowskiego. Na sejmie książęcym we Wrocławiu 9 V 1329 r. Henryk żagański przekazał w lenno (in feudum) królowi Czech Janowi Luksemburskiemu wszystkie swoje ziemie cum amicis quoque ac fidelibus nostris consilio diligenti ac deliberacione matura, accedentibus eciam favore et consensu eorundem ${ }^{11}$.

1331

- 1-2 X, Głogów, sejmik Księstwa Głogowskiego. Jan Luksemburski przyrzekł na nim, że Głogów i związany z nim obszar nie zostaną odłączone od Korony Czech oraz od miasta i Księstwa Wrocławskiego oraz pozostaną

5 UO, nr 106; F.W. Sommersberg, Silesiacarum rerum Scriptores..., t. III, Leipzig 1730, s. 138.

$6 \mathrm{UO}, \mathrm{nr} 115$.

7 Lehns- und Besitzurkunden Schlesiens..., cz. I, Leipzig 1881 (dalej: GM I), s. 120-125; UO, nr 119.

8 J. Klapper, Ein Großglogauer Zinsregister aus der Zeit um 1315, „Zeitschrift des Vereins für Geschichte und Alterthum Schlesiens" (dalej: ZVGS) 1940, t. 74, s. 126-148; A. Moeppert, Das Zinsregister des Fürstentums Glogau aus dem Anfang des 14. Jahrhunderts, ZVGS, t. 75, 1941, s. 89-96. 
we władaniu jego dziedziców ${ }^{12}$. Wystawił też 2 X 1331 r. osobny dokument miastu Głogów pozwalający mu ścigać i karać naruszycieli pokoju (pacis turbatores) w weichbildzie głogowskim oraz na terytorium wrocławskim, kłodzkim i zgorzeleckim ${ }^{13}$.

\section{9}

- 3 II, Głogów, sejmik Księstwa Głogowskiego. Dokument księcia Henryka potwierdzający i odnawiający poprzedni dla Głogowa z 2 X $1331 \mathrm{r.}^{14}$

\section{1}

- 18 III, Głogów (?), sejmik Księstwa Głogowskiego. Hołd ziem, manów i miast. Reprezentacja stanów (2 manów i 2 mieszczan) mogła się zwrócić do księcia o zwolnienie od złożonego hołdu a książę przyrzekł zwolnienie ich ze złożonej przysięgi ${ }^{15}$.

\section{8}

- (?) Zielona Góra (?) sejmik weichbildu zielonogórskiego. Manowie weichbildu wraz z gminą Zielonej Góry uchwalili wilkierz dotyczący prawa spadkowego i majątkowego małżeńskiego ${ }^{16}$.

- (?) Kożuchów, sejmik weichbildu zielonogórskiego albo wspólny z weichbildem kożuchowskim. Konfirmacja w/w wilkierza przez książąt głogowskich i szprotawskich (Henryk Starszy i Henryk Młodszy Rumpold) ${ }^{17}$.

\section{9}

- Przed 9 I (może już w 1418 r.) (?) sejmik weichbildu kożuchowskiego. Manowie i gmina Kożuchowa uchwalili na nim własny wilkierz dotyczący prawa spadkowego i majątkowego małżeńskiego ${ }^{18}$.

- 9 I, (Wielki) Głogów, sejmik Księstwa Głogowskiego. Konfirmacja tego wilkierza przez tę samą parę książąt ${ }^{19}$.

\section{2}

- Po 22 X, Głogów (?) sejmik Księstwa Głogowskiego. Henryk głogowski zwołuje manów i miasta Księstwa Głogowskiego ${ }^{20}$.

12 Ibidem, s. 134-5 (1 X), 135 (2 X).

13 F. Minsberg, Geschichte der Stadt und Festung Gross-Glogau, t. I, Glogau 1853, s. 337-9.

14 Ibidem, s. 339-40.

15 CDS, t. XXVIII, s. 33, nr 114.

16 J.J. Weingarten, Fasciculi diversorum iurium..., Nürnberg 1690, Liber I, P. III, s. 18; A. Wentzel, J. Wentzel, Das jetzt bestehende Provinzial=Recht des Herzogthums Schlesien und der Graffschft Glatz, Zweiter Theil. Lokal=Recht. Das jetzt bestehende Lokal-Recht des Herzogthums Schlesien und der Graffschft Glatz, Breslau, Ratibor und Pleß 1840, s. 205-206; O. Wolff, Geschichte der Stadt Grünberg in Niederschlesien von ihrer Entstehung bis zur Entstehung der Reformation, Grünberg 1848, s. 62-64; F. Ohnesorge, Zur Quellenkunde der Geschichte von Grünberg in Schlesien, [w:] Festschrift zur Feier des fünffzigjährigen Bestehens Friedrich-Wilhelms-Realgymnasium Grünberg in Schlesien, Grünberg 1903, s. 6-7.

17 Ibidem.

18 A. Wentzel, J. Wentzel, op. cit., s. 189-191.

Ibidem.

Codex diplomaticus Brandenburgensis (dalej: CDB), wyd. A. Riedel, cz. II, t. 3, Berlin, s. 429. 


\section{8}

- Przed 13 V, Świebodzin (?) sejmik weichbildu świebodzińskiego. Manowie i gmina Świebodzina uchwaliły własny wilkierz dotyczący prawa spadkowego i majątkowego małżeńskiego ${ }^{21}$.

- 13 V, Krosno, sejmik weichbildu krośnieńskiego i świebodzińskiego. Konfirmacja w/w wilkierza przez księcia krośnieńsko-świebodzińskiego Wacława $^{22}$.

1469

- 5 III, Kożuchów, sejmik Księstwa Kożuchowskiego. Przywilej dla Świebodzina wydany przez księcia kożuchowskiego Henryka XI „w obecności i za radą wszystkich manów tego księstwa"23.

\section{6}

- 13 III, Zielona Góra, sejmik Księstwa Kożuchowskiego. Hołd stanów Zielonej Góry, Kożuchowa, Sulechowa i Świebodzina złożony Janowi żagańskiemu ${ }^{24}$.

- 19 III, Kożuchów, sejmik Księstwa Kożuchowskiego. Wzięli w nim udział prałaci, panowie i miasta ${ }^{25}$.

\section{7}

- (?) Kożuchów, sejmik Księstwa Kożuchowskiego. Trzydniowe obrady po których zawarto zawieszenie broni Jana żagańskiego z margrabią brandenburskim Janem ${ }^{26}$.

\section{8}

- 8-11 IX, Głogów, sejmik Księstwa Głogowskiego części cieszyńskiej (z udziałem rycerstwa i mieszczan w sprawie hołdu) ${ }^{27}$. W drugiej części miasta Jan żagański zwołał mieszczan swojej części i górowian ${ }^{28}$.

- 29 IX, (?) sejmik Księstwa Głogowskiego. Sprawa kontrybucji od poddanych $^{29}$.

- 26 X, Głogów (?) sejmik Księstwa Głogowskiego. Sprawy wojskowe miast i wasali ${ }^{30}$.

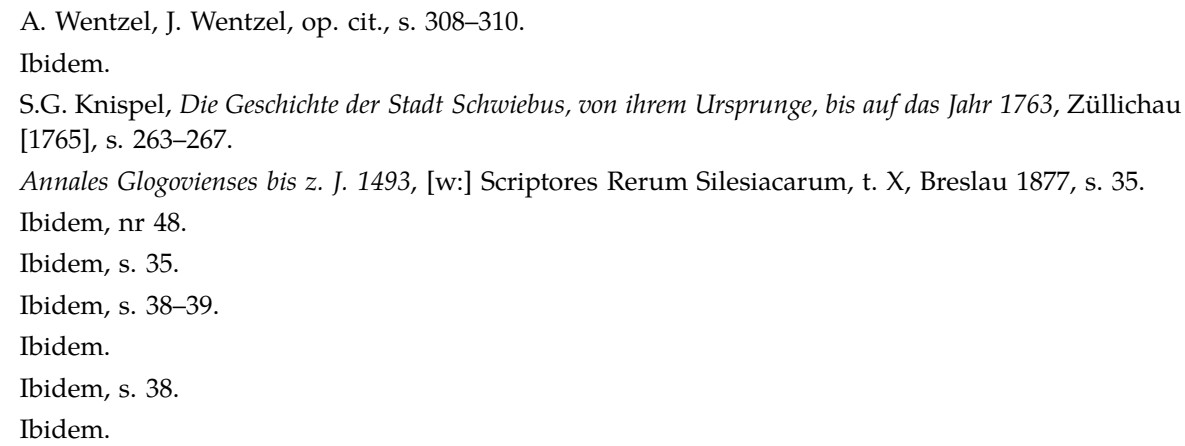




\section{0}

- 5 III, Głogów, zjazd Jana żagańskiego i miasta Głogowa ${ }^{31}$.

- 11 III, Głogów, zamek (pretorium) i rynek, godz. 22, sejmik Księstwa Głogowskiego części książęcej. Książę Jan zwołał mieszczan, najemników (stipendiarios) i szlachtę 32 .

- 12 III, Głogów, zamek. Jan zwołał kapitułę w sprawie jej opodatkowania ${ }^{33}$.

- 27 III, Głogów, rynek. Jan zażądał hołdu od mieszczan drugiej części Głogowa ${ }^{34}$.

- 9-10 IV, Głogów. Zjazd Jana ze stanami ziemskimi weichbildu górowskiego, wasalami dystryktu głogowskiego i duchowieństwem ${ }^{35}$.

- 23-24 VI, Głogów (?). Ugoda Jana z Górą ${ }^{36}$.

- 12-14 VIII, Prochowice, sejmik Księstwa Głogowskiego. Wzmianka37.

\section{1}

- 18 VI, Głogów, sejmik Księstwa Głogowskiego. Wziął w nim udział orator królewski. Nastąpiło połączenie obu części Głogowa oraz konfirmacja Jana żagańskiego jako pana Księstwa Głogowskiego, następnie Jan ze wszystkimi miastami i szlachtą złożył hołd królowi Maciejowi Korwinowi pod warunkiem, że gdy umrze bez dziedziców to władzę w nim obejmie król ${ }^{38}$.

- 7 XI, Kożuchów (?), sejmik weichbildu kożuchowskiego. Pisemne zobowiązanie miasta i manów weichbildu kożuchowskiego wobec służebników księcia Jana na kwotę 1948 3/4 florenów reńskich ${ }^{39}$.

\section{7}

- 6-13 I, Głogów, sejmik Księstwa Głogowskiego. Wzmianka ${ }^{40}$.

- 24 VIII, Głogów, sejmik Księstwa Głogowskiego. Wzmianka ${ }^{41}$.

\section{8}

- 9 III, Głogów. Jan zwołał mieszczan głogowskich i ustanowił nowego burmistrza i konsulów ${ }^{42}$. Pismo Jana żagańskiego usprawiedliwiające jego postawę naciskiem militarnym króla ${ }^{43}$.

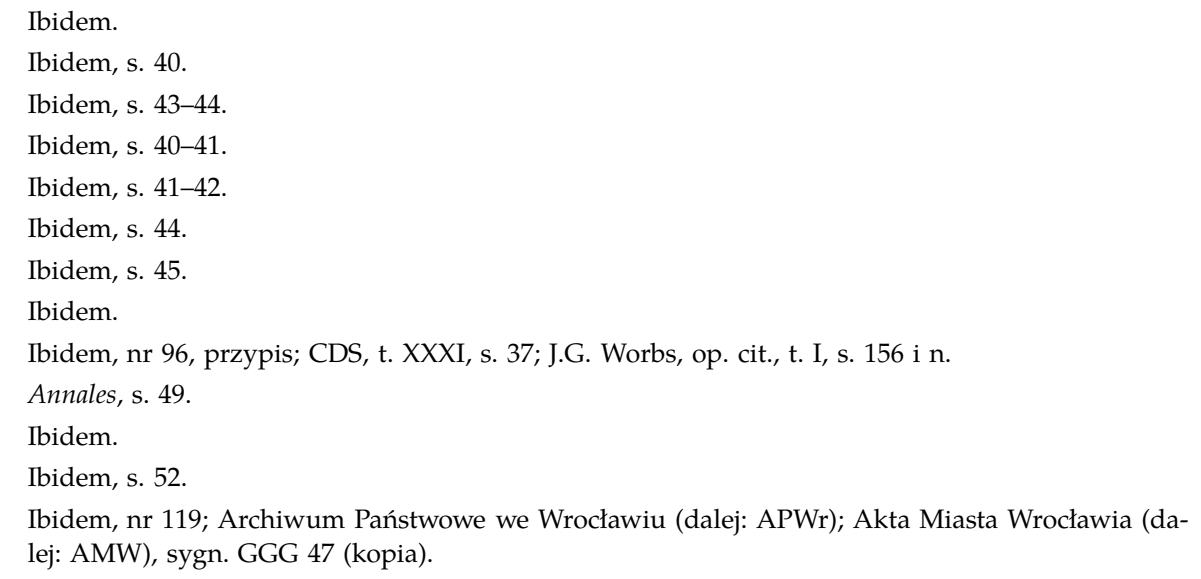


- 29 VIII-5 IX, Głogów, zamek, sejmik Księstwa Głogowskiego. Zwołany samorzutnie w sprawie księcia Jana ${ }^{44}$.

- 19 XI, (?), sejmik Księstwa Głogowskiego. Hołd stanów głogowskich złożony Maciejowi Korwinowi ${ }^{45}$.

- 16 XII, Głogów, zamek. Starosta królewski przyjął hołd Głogowa i ustanowił nowych konsulów ${ }^{46}$.

- 26 XII, Głogów, zamek. Hołd kleru złożony staroście królewskiemu ${ }^{47}$.

- 28 XII, Głogów, zamek, sejmik weichbildu głogowskiego. Hołd szlachty dystryktu głogowskiego złożony staroście królewskiemu ${ }^{48}$.

1489

- 3 I, Szprotawa, sejmik szlachty weichbildu szprotawskiego. Szlachta i miasto uznały zwierzchnictwo starostów królewskich ${ }^{49}$.

- 1 V, Głogów, zamek, sejmik Księstwa Głogowskiego. Zwolnienie miast i szlachty od hołdu złożonego Janowi i złożenie go królowi ${ }^{50}$.

- (?) sejmik weichbildu ścinawskiego i rudniańskiego (z udziałem szlachty i miast). Wzmianka ${ }^{51}$.

\section{0}

- (?) Sejmik ścinawsko-rudniański. Wzmianka ${ }^{52}$.

- (?) sejmik Księstwa Głogowskiego. Hołd stanów głogowskich złożony Janowi Korwinowi ${ }^{53}$.

- 27 II, (?) sejmik Księstwa Głogowskiego. Sprawa przywilejów podatkowych $^{54}$.

\section{1}

- 12 V, Kożuchów, zamek, sejmik weichbildu kożuchowskiego i głogowskiego. Wydano na nim jakieś wyroki śmierci ${ }^{55}$.

- 1-9 XI, Głogów, sejmik weichbildu głogowskiego (z udziałem szlachty i miasta Głogowa). Powołano na nim deputację do króla Władysława w sprawie konfirmacji przywilejów, które potwierdził im poprzednio Maciej Korwin ${ }^{56}$. 


\section{3}

- 31 I, Głogów, zamek. Zgromadzenie z udziałem starosty Księstwa Głogowskiego (Judex pan Jan Polak universalis capitaneus), 4 asesorów z weichbildu 1501 górowskiego (2 baronów i 2 mieszczan) i innych miast ${ }^{57}$.

- 10 II, (?) sejmik Księstwa Głogowskiego. Układ manów księstwa z miastami w sprawie jurysdykcji nad osobami im podległymi ${ }^{58}$.

\section{0}

- (?) Zjazd rycerstwa głogowskiego. Relacja Pakossa von Salza doktora i starosty Księstwa Głogowskiego z 22 XII 1510 r. skierowana do miasta Wrocławia informująca o tym zjeździe ${ }^{59}$.

\section{7}

- 4 VI, Głogów, sejmik Księstwa Głogowskiego. Rewers rycerstwa i manów Księstwa Głogowskiego ${ }^{60}$.

\section{9}

- Po 16 VIII, Głogów, wydział ziemski albo sejmik Księstwa Głogowskiego. Sigismundus I rex Poloniae commissariis ad Glogoviensem conuentum deputatis, Kraków 16 VIII 153961.

- Po 28 IX, Głogów, wydział ziemski albo sejmik Księstwa Głogowskiego. Sigismundus I rex Poloniae commissariis ad Glogouiensem conuentum deputatis, Kraków 28 IX 153962.

1541

- (?) Laudum stanów głogowskich dotyczące m.in. rynsztunku rycerskiego (Heergeräthe) ${ }^{63}$.

\section{1}

- Przed 22 VII, Głogów (?) zjazd miast (6). Cesarz Ferdynand zatwierdził dokumentem wydanym w Wiedniu 22 VII 1561 r. sześciu miastom Księstwa Głogowskiego przywilej z 1511 r. oraz prawo wolnego wyboru burmistrza i rajców ${ }^{64}$.

57 Ibidem, s. 64.

581507 o.T. Sagan. Bürgermeister und Rathmannen vidimiren folgenden Pergamentbrief:1501, am tage Scolastice, o.O. Die Mannen des Fürstentums Glogau einigen sich mit den Städten wegen des Gerichtsbarkeit über ihre Hintersassen. Or. Perg. dessen S. fehlt, [w:] CDS, t. XXVIII, Gleinitz (Familienbesitz des Geschlechts v. Niebelschütz Seit 1447) Schloßarchiv nr 10.

59 APWr; Dokumenty miasta Wrocławia (dalej: DMW), nr 98.

60 GM I, s. 262-3.

61 Biblioteka Kórnicka PAN, BK 00218 „Thomus Decimus Octauus Epistolarum Legationum ..., cd. 3, k 246v.-247.

62 Ibidem, k. 247-247v.

63 Stylo, Das Provinzialrecht von Niederschlesien historiach=kritisch erlätert..., Breslau 1830, s. 387, 388, $390 \mathrm{z}$ powołaniem się na księgi sądowe Mannrechtu głogowskiego (Glogisches Manngerichts $=$ Abschrifts=Buch von 1541 und 1545, fol. 12 b).

64 H. Schmidt, Geschichte der Stadt Grünberg, Grünberg 1922, s. 456; S.G. Knispel, op. cit., s. 207-210 in extenso. 


\section{7}

- Przed 7 II, Głogów (?) sejmik Księstwa Głogowskiego. Suplika panów i rycerstwa wszystkich weichbildów Księstwa Głogowskiego do cesarza z 7 II 1597 wręczona cesarzowi 13 II 1597 r. ${ }^{65}$

\section{2}

- 30 III, Głogów, zjazd miast (4). Uchwała w sprawie deputowanego ad publica $^{66}$.

\section{5}

- 17 IX, Głogów, zjazd miast (6). Zwołany przez Urząd Królewski w Głogowie 7 XI. Tekst propozycji (8 pkt) i uchwały (8 pkt) tego zjazdu ${ }^{67}$.

\section{6}

- 25 IX, Głogów, zjazd miast (6). 11 IX burmistrz i rajcy Szprotawy skierowali pismo do Urzędu Królewskiego w Głogowie w sprawie finansowanie deputacji ad publica przez niektóre miasta ${ }^{68}$. Uchwała zjazdu określająca zasady finansowania tej deputacji ${ }^{69}$.

\section{7}

- 27 X, Głogów, zjazd miast (5). Zawarto na nim kontrakt w sprawie wysyłania deputowanego ad publica ${ }^{70}$.

\section{8}

- 26 VIII, Głogów, zjazd miast (4). Umowa w sprawie deputowanego ad publica $^{71}$.

\section{6}

- 17 IX, Świebodzin, ratusz, sejmik weichbildu świebodzińskiego. Zebrały się stany całego okręgu w związku z komisją księcia-elektora, która przedstawiła sprawy dotyczące cła i akcyzy w Brandenburgii ${ }^{72}$.

\section{3-1717}

- Protokół sejmiku weichbildowego w Szprotawie (Creyß-Protocoll bey Creyß Versammlung in Sprottau) $)^{73}$.

\section{4}

- 25 IX, Głogów, zjazd miast (4). Przed 6 IX pismo syndyka miast Księstwa Głogowskiego do Urzędu Królewskiego w Głogowie z prośbą o zwołanie

\footnotetext{
65 Archiwum Państwowe w Zielonej Górze (dalej: APZG), Akta miasta Szprotawy (dalej: AMS), sygn. 218.

66 Ibidem, sygn. 952.

67 Ibidem, sygn. 19.

68 Ibidem, sygn. 952.

69 Ibidem.

70 Ibidem.

71 Ibidem.

72 G. Zerndt, Geschichte von der Stadt und Kreis Schwiebus, cz. II, Schwiebus 1912, s. 351.

73 AMS, sygn. 1040 (mikrofilm).
} 
zjazdu w celu wyboru deputowanego ad publica (Ober- undt. Fürsten Recht $)^{74}$. Pismo Urzędu z 15 IX zwołujące zjazd, skierowane do wszystkich miast ${ }^{75}$. Pełnomocnictwo udzielone 24 IX dwom rajcom przez burmistrza i rajców Szprotawy na ten zjazd ${ }^{76}$.

\section{9}

- 21-23 III, Głogów. Relacja z odbytego wydziału ziemskiego (Landes Zusammenkunfft) $\mathrm{z}$ udziałem przedstawicieli weichbildów i miast (15 pkt) ${ }^{77}$. Relacja dotycząca spraw miejskich (8 pkt) sporządzona w Szprotawie 26 III $1709 \mathrm{r}^{78}$

1729

- 22 IX, Głogów, dom ziemski, kolegium ziemskie (z udziałem deputowanych kapituły katedralnej i miast). Patent wzywający z 9 IX 1729 r. wystawiony na zamku głogowskim przez głogowskiego starostę ziemskiego oraz radców i asesorów Księstwa Głogowskiego, adresowany do Szprotawy ${ }^{79}$.

\section{2}

- (?) Wzmianka o sejmiku weichbildowym odbytym w Świebodzinie ${ }^{80}$. 1786

- (?) Głosowanie stanów ziemskich powiatu głogowskiego w sprawie wyboru deputowanych do komisji ustawodawczej (Vota der Landstände Glog. Kreises zur Wahl der Deputirten der landständischen Gesetz-Kommision) ${ }^{81}$.

Z przedstawionego wykazu wynika, że genezy sejmiku Księstwa Głogowskiego można już upatrywać na początku drugiej połowy XIII stulecia. Zgromadzenie rycerstwa związanego z księciem Konradem, który już od 1249 r. przejawiał dążenie do samodzielności politycznej i uniezależnienia się od swoich trzech braci (Bolesław II Rogatka, Henryk III Biały, Władysław), jest tego pierwszym przejawem. Ośrodkiem jego politycznej aktywności stawał się coraz częściej Głogów. Być może tutejsze rycerstwo było naturalnym sojusznikiem księcia $w$ realizacji tego celu. Wzrost roli rycerstwa i szlachty można zaobserwować w tym czasie także w innej części Śląska. Władysław opolski wydał w 1254 r. dokument, zezwalający na lokację Bytomia na prawie niemieckim, z charakterystyczną klauzulą ex deliberato consilio nobilium no-

\footnotetext{
Ibidem, sygn. 952.

Ibidem.

Ibidem.

AMS, sygn. 36, s. 1-6.

Ibidem, s. 7-8.

Ibidem, sygn. 41.

S.G. Knispel, op. cit., s. 210.

81 APWr, Rep. 24, sygn. 253, ss. 51.
} 
strorum $^{82}$. O obecności, dobrej woli, zwoływaniu, zapytywaniu, radzie, naradzie i zgodzie szlachty, wiernych, przyjaciół i mędrców, związanych już nie tylko $\mathrm{z}$ osobą księcia ale także $\mathrm{z}$ jego ziemią, informują wprost dokumenty ze schyłku XIII i początku XIV stulecia. Dotyczyły one udziału głównie w czynnościach prawnych o charakterze majątkowym, odnoszących się nie tylko do poddanych księcia (nadawania praw i zwalniania od obowiązków) ale także do panującej rodziny. Jest to najwcześniej widoczne $\mathrm{w}$ dokumencie podziału dużego terytorium (północno-zachodnia część Dolnego Śląska i południowo-zachodnia Wielkopolski) Piastów głogowskich z 1312 r., aspirujących przecież do tronu polskiego, który został dokonany przy bezpośrednim udziale głogowskich stanów ziemskich. W relacjach między książętami i stanami coraz ważniejszą rolę zaczęły odgrywać hołdy, składane przez poszczególne stany albo wspólnie przez kilka stanów, na sejmikach hołdowniczych. Ich istotą było formalnoprawne uznanie zwierzchnictwa politycznego rodziny panującej i konkretnego księcia, związane $\mathrm{z}$ obowiązkiem dochowania mu wierności. Miały one jednak charakter warunkowy, wymagały bowiem od księcia ekwiwalentnego zobowiązania do poszanowania praw i wolności stanów. Przybierało ono formę odrębnego konfirmacyjnego dokumentu, zwanego później rewersem. Dopiero spełnienie obu tych publiczno-prawnych aktów umożliwiało sprawowanie rządów książęcych. Zmiana warunków tego swoistego kontraktu politycznego wymagała zgody obu stron. Dotyczyło to także uznania zwierzchnictwa lennego króla czeskiego przez książąt głogowskich w 1329 r., co nastąpiło po uprzednim zasięgnięciu rady i uzyskaniu zgody stanów, zgromadzonych na sejmiku całego księstwa. W drugiej i trzeciej dekadzie XV w. uwagę zwraca prawotwórcza aktywność kilku sejmików weichbildowych w zakresie prawa prywatnego wspólnego dla szlachty i miasta weichbildowego. W ostatnim ćwierćwieczu XV stulecia uderza z kolei intensywność, zmienność i różnorodność form politycznej komunikacji księcia i poszczególnych stanów, uwzględniająca ich usytuowanie w strukturach politycznych nie tylko Księstwa Głogowskiego, ale także całego Śląska i Królestwa Czech. Zaskakuje w tym kontekście wysyłanie na sesje wydziału lub sejmiku głogowskiego w 1539 r. deputowanych króla polskiego Zygmunta Starego, choć Jagiellonowie przestali panować na Śląsku i w Księstwie Głogowskim w 1526 r. Wykaz potwierdził wyjątkową w skali całego Śląska rolę miast weichbildowych przejawianą $\mathrm{w}$ formie odrębnych zjazdów, widocznych zwłaszcza $\mathrm{w}$ ostatnich trzech dekadach XVII w. w związku z ich udziałem w ogólnośląskich organach stanowych. Kształtujące się od przełomu XIII i XIV w. formy partycypacji stanów w życiu politycznym Księstwa Głogowskiego zostały zlikwidowane w latach czterdziestych XVIII w., po aneksji Śląska przez Królestwo Pruskie. 
Hohenzollernowie za godne kontynuacji uznali tylko sejmiki weichbildowe, które funkcjonowały nadał w nowych, choć nawiązujących do dawnych granic, jednostkach podziału terytorialnego, zwanych powiatami (Kreis). Sejmiki odgrywały w nich już mniejszą rolę. Pewien wzrost ich znaczenia wiązał się z utworzeniem przez króla pruskiego w 1770 r. organizacji kredytowej dla szlachty, zwanej Ziemstwem Śląskim (Schlesische Landschaft). Składało się ono z ośmiu ziemstw księstw, w tym Ziemstwa Głogowsko-Żagańskiego, w których przewidziano funkcjonowanie sejmików powiatowych. W 1786 r. odbył się taki sejmik w powiecie głogowskim, liczącym wówczas około 40 osiadłych ziemian. Przedmiotem jego obrad była sprawa wykraczająca poza działalność kredytową, dotyczyła bowiem jego udziału w procedurze legislacyjnej mającej na celu przygotowanie projektu kodeksu prawa prowincjonalnego Śląska. Był to już jednak tylko jeden $\mathrm{z}$ ostatnich refleksów dawnej świetności instytucji stanowych Księstwa Głogowskiego.

\section{Bibliografia}

\section{Źródła i archiwalia}

Annales Glogovienses bis z. J. 1493, [w:] Scriptores Rerum Silesiacarum, t. X, Breslau 1877.

Archiwum Państwowe w Zielonej Górze, Akta miasta Szprotawy, sygn. 218.

Archiwum Państwowe we Wrocławiu, Akta Miasta Wrocławia, sygn. GGG 47 (kopia).

Biblioteka Kórnicka PAN, BK 00218 „Thomus Decimus Octauus Epistolarum Legationum ..., cd. 3, k 246v.-247.

Codex Diplomaticus Silesiae, t. VII, cz. 2, Breslau 1875, Regesten zur schlesischen Geschichte.

Codex diplomaticus Brandenburgensis, wyd. A. Riedel, cz. II, t. 3, Berlin.

Codex Diplomaticus Silesiae, t. IV.

Lehns- und Besitzurkunden Schlesiens und seiner einzelnen Fürstenthümer im Mittelalter, wyd. C. Grünhagen, H. Markgraf, cz. II, Leipzig 1883.

Lehns- und Besitzurkunden Schlesiens und seiner einzelnen Fürstenthümer im Mittelalter, cz. I, Leipzig 1881.

Neues Archiv für die Geschichte Schlesiens und der Lausitz, t. II, wyd. J.G. Worbs.

Registrum St. Wenceslai, Codex Diplomaticus Silesiae, t. VI, s. 177, nr I.

Sommersberg F.W., Silesiacarum rerum Scriptores..., t. III, Leipzig 1730.

Urkundensammlung zur Geschichte des Fürstentums Oels bis zum Aussterben der Piastischen Herzogslinie, wyd. W. Haeusler, Breslau 1883. 


\section{Literatura}

Klapper J., Ein Großglogauer Zinsregister aus der Zeit um 1315, „,Zeitschrift des Vereins für Geschichte und Alterthum Schlesiens" 1940, t. 74.

Knispel S.G., Die Geschichte der Stadt Schwiebus, von ihrem Ursprunge, bis auf das Jahr 1763, Züllichau [1765].

Minsberg F., Geschichte der Stadt und Festung Gross-Glogau, t. I, Glogau 1853.

Moeppert A., Das Zinsregister des Fürstentums Glogau aus dem Anfang des 14. Jahrhunderts, „Zeitschrift des Vereins für Geschichte und Alterthum Schlesiens” 1941, t. 75.

Ohnesorge F., Zur Quellenkunde der Geschichte von Grünberg in Schlesien, [w:] Festschrift zur Feier des fünffzigjährigen Bestehens Friedrich-Wilhelms-Realgymnasium Grünberg in Schlesien, Grünberg 1903.

Ptak M., Zgromadzenia i urzędy stanowe księstwa gtogowskiego od początku XIV w. do 1742 r., Acta Universitatis Wratislaviensis nr 1344, Prawo CCX, Wrocław 1991.

Weingarten J.J., Fasciculi diversorum iurium..., Nürnberg 1690, Liber I, P. III.

Wentzel A., Wentzel J., Das jetzt bestehende Provinzial=Recht des Herzogthums Schlesien und der Graffschft Glatz, Zweiter Theil. Lokal=Recht. Das jetzt bestehende Lokal-Recht des Herzogthums Schlesien und der Graffschft Glatz, Breslau, Ratibor und Pleß 1840.

Wolff O., Geschichte der Stadt Grünberg in Niederschlesien von ihrer Entstehung bis zur Entstehung der Reformation, Grünberg 1848.

Zimmermann F.A., Beiträge zur Beschreibung von Schlesien, t. X, Brieg 1791.

Stylo, Das Provinzialrecht von Niederschlesien historiach=kritisch erlätert..., Breslau 1830.

Schmidt H., Geschichte der Stadt Grünberg, Grünberg 1922.

Zerndt G., Geschichte von der Stadt und Kreis Schwiebus, cz. II, Schwiebus 1912. 